\title{
Assessment of Genetic Mutations DMD, DYSF, EMD, LMNA, DUX4, DMPK, ZNF9, PABPN1 Genes Induction Duchenne Muscular Dystrophy
}

\author{
Shahin Asadi ${ }^{*}$, Vida Vahdani $\mathrm{Kia}^{2}$, Rana Bagheri' ${ }^{2}$, Mahsa Jamali ${ }^{3}$ and Samaneh Sadeh Dell ${ }^{3}$ \\ ${ }^{1}$ student of Molecular Genetics, Director of the Division of Medical Genetics and Molecular Research, Molecular Genetics-IRAN-TABRIZ \\ ${ }^{2}$ Master of Molecular Biology-Genetics, Director of the Division of Medical Genetics and Molecular Research, Molecular Genetics-IRAN-TABRIZ \\ ${ }^{3}$ Master of Molecular Genetics, Director of the Division of Medical Genetics and Molecular Research, Molecular Genetics-IRAN-TABRIZ
}

Received: August 24, 2017; Accepted: August 31, 2017; October 12, 2017

*Corresponding author: Shahin Asadi, Director of the Division of Medical Genetics and Molecular Research, Molecular Genetics-IRAN-TABRIZ, Tel: +989379923364;E-mail: shahin.asadi1985@gmail.com

\section{Abstract}

Background Importance and Aim: Our aim is to investigate the genetic and genetic patterns of Duchenne muscular dystrophy.

Methodology: In this study we have analyzed 20 people. 10 patients Duchenne muscular dystrophy disease and 10 persons control group. The genes DMD, DYSF, EMD, LMNA, DUX4, DMPK, ZNF9, PABPN1 analyzed in terms of genetic mutations made. In this study, people who have genetic mutations were targeted, with nervous disorders, Duchenne muscular dystrophy disease.

Results and Conclusion: In fact, of all people with Duchenne muscular dystrophy disease. 10 patients Duchenne muscular dystrophy disease had a genetic mutation in the genes DMD, DYSF, EMD, LMNA, DUX4, DMPK, ZNF9, PABPN1 Duchenne muscular dystrophy disease. Any genetic mutations in the target genes control group did not show.

Keywords: Genetic study; Duchenne muscular dystrophy disease; Mutations The genes DMD, DYSF, EMD, LMNA, DUX4, DMPK, ZNF9, PABPN1

\section{Introduction}

Duchenne muscular dystrophy (DMD) is a severe type of muscular dystrophy.[1] The symptom of muscle weakness usually begin around the age of four in boys and worsens quickly. [2] Typically muscle loss occurs first in the upper legs and pelvis followed by those of the upper arms. This can result in trouble standing up.[1] Most are unable to walk by the age of 12.[2] Affected muscles may look larger due to increased fat content. Scoliosis is also common. Some may have intellectual disability. Females with a single copy of the defective gene may show mild symptoms.[1]

The disorder is X-linked recessive. About two thirds of cases are inherited from a person's parents, while one third of cases are due to a new mutation. It is caused by a mutation in the gene for the protein dystrophin. Dystrophin is important to maintain the muscle fiber cell membrane. Genetic testing can often make the diagnosis at birth. Those affected also have a high level of creatine kinase in their blood.[1]

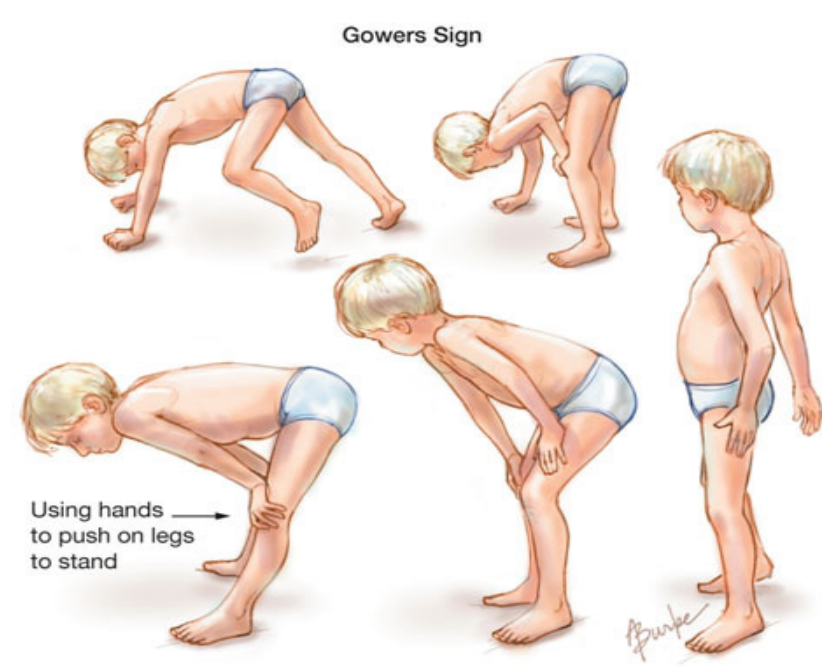

Figure 1: Schematic View of Child with Duchenne Muscular Dystrophy. 
No cure for muscular dystrophy is known. Physical therapy, braces, and corrective surgery may help with some symptoms.[2] Assisted ventilation may be required in those with weakness of breathing muscles.[1] Medications used include steroids to slow muscle degeneration, anticonvulsants to control seizures and some muscle activity, and immunosuppressant's to delay damage to dying muscle cells. $[3,4]$

DMD affects about one in 5,000 males at birth. It is the most common type of muscular dystrophy.[1] The average life expectancy is 26; however, with excellent care, some may live into their 30 s or 40 s. [5-8] Gene therapy, as a treatment, is in the early stages of study in humans.[9,10][Figure 1]

\section{Materials and Methods}

In this study, 10 patients with Duchenne muscular dystrophy disease, and 10 persons control group were studied. Peripheral blood samples from patients and parents with written permission control were prepared. After separation of serum, using Real Time-PCR technique of tRNA molecules was collected. To isolate Neuroglial cells erythrocytes were precipitated from hydroxyethyl starch (HES) was used. At this stage, HES solution in ratio of 1 to 5 with the peripheral blood of patients and controls were mixed. After 60 minutes of incubation at room temperature, the supernatant was removed and centrifuged for $14 \mathrm{~min}$ at 400 Gera. The cell sediment with PBS (phosphate buffered saline), pipetazh and slowly soluble carbohydrate ratio of 1 to 2 onficole (Ficol) was poured in the $480 \mathrm{G}$ was centrifuged for 34 minutes. Mono nuclear Neuroglial cells also are included, has a lower density than ficole and soon which they are based. The remaining erythrocytes have a molecular weight greater than Ficol and deposited in test tubes. [11-18]

The supernatant, which contained the mono nuclear cells, was removed, and the 400 Gera was centrifuged for 12 minutes. Finally, the sediment cell, the antibody and Neuroglial cells was added after 34 minutes incubation at $5{ }^{\circ} \mathrm{C}$, the cell mixture was passed from pillar LSMACS. Then the cells were washed with PBS and attached to the column LSMACSS pam Stem cell culture medium containing the transcription genes DMD, DYSF, EMD, LMNA, DUX4, DMPK, ZNF9, PABPN1, and were kept. [19]

To determine the purity of Neuroglial cells are extracted, flow cytometry was used. For this purpose, approximately 4-5 $\times 10^{3}$ Neuroglial cells were transfer red to $1.5 \mathrm{ml}$ Eppendorf tube and then were centrifuged at $2000 \mathrm{rpm}$ for 7 minutes at time. Remove the supernatant culture medium and there maining sediment, $100 \mu \mathrm{l}$ of PBS buffer was added. After adding 5-10 $\mu \mathrm{l}$ PE monoclonal anti body to the cell suspension for $60 \mathrm{~min}$ at $4^{\circ} \mathrm{C}$ incubated and read immediately by flow cytometry. For example, rather than control anti body Neuroglial cells PE, igg1 negative control solution was used. [20]

\section{Total mRNA Extraction Procedure Includes}

1. $1 \mathrm{ml}$ solution spilled Qiazolon cells, and slowly and carefully mixed and incubated at room temperature for 5 minutes. Then $200 \mu \mathrm{l}$ chloroform solution to target mix, and then transfer the micro tubes was added, and the shaker well was mixed for 15 seconds. The present mix for 4 minutes at room temperature and then incubated for $20 \mathrm{~min}$ at $4^{\circ} \mathrm{C}$ and was centrifuged at 13200 rpm era. Remove the upper phase product was transfer reductase new micro tube and to the one times the volume of cold ethanol was added. The resulting mixture for 24 hours at $-20^{\circ} \mathrm{C}$ was incubated. [21-27]

2. Then for $45 \mathrm{~min}$ at $4^{\circ} \mathrm{C}$ and was centrifuged at $12000 \mathrm{rpm}$ era. Remove the supernatant and the white precipitate, $1 \mathrm{ml}$ of cold $75 \%$ ethanol was added to separate the sediment from micro tubes were vortex well. The resulting mixture for $20 \mathrm{~min}$ at $4^{\circ} \mathrm{C}$ and by the time we were centrifuged $12000 \mathrm{rpm}$. Ethanol and the sediment was removed and placed at room temperature until completely dry deposition. The precipitate was dissolved in $20 \mu \mathrm{l}$ sterile water and at a later stage, the concentration of extracted mRNA was determined. [28]

To assessment the quality of mi-rna, the RT-PCR technique was used. The cDNA synthesis in reverse transcription reaction (RT) kit (Fermentase K1622) and $1 \mu$ loligoprimers 18 (DT) was performed. Following the PCR reaction $2 \mu \mathrm{m}$ dNTP, $1 \mu \mathrm{g}$ cDNA, ferment as PCR buffer 1X, 0 / 75 $\mu \mathrm{m}$ mgcl2, $1.25 \mathrm{U} / \mu \mathrm{L}$ Tag DNA at $95^{\circ} \mathrm{C}$ for $4 \mathrm{~min}, 95^{\circ} \mathrm{C}$ for $30 \mathrm{~s}$, annealing temperature $58^{\circ} \mathrm{C}$ for $30 \mathrm{~s}$, and $72{ }^{\circ} \mathrm{C}$ for 30 seconds, 35 cycles were performed. Then $1.5 \%$ agarose gel, the PCR product was dumped in wells after electrophores is with ethidium bromide staining and color was evaluated. [29-30]

\section{Results}

The results of the PCR and RT-PCR reaction for Duchenne disease target genes are as follows:[Figure 2-8]

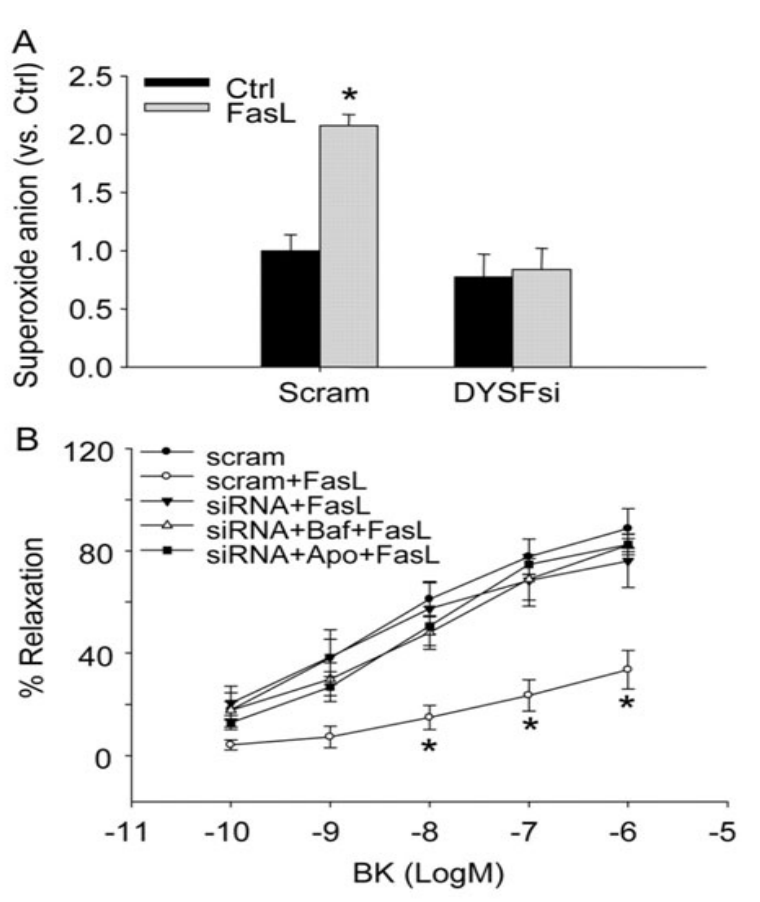

Figure 2: Diagnosis of DYSF gene expression in patients with Duchenne Muscular Dystrophy. 

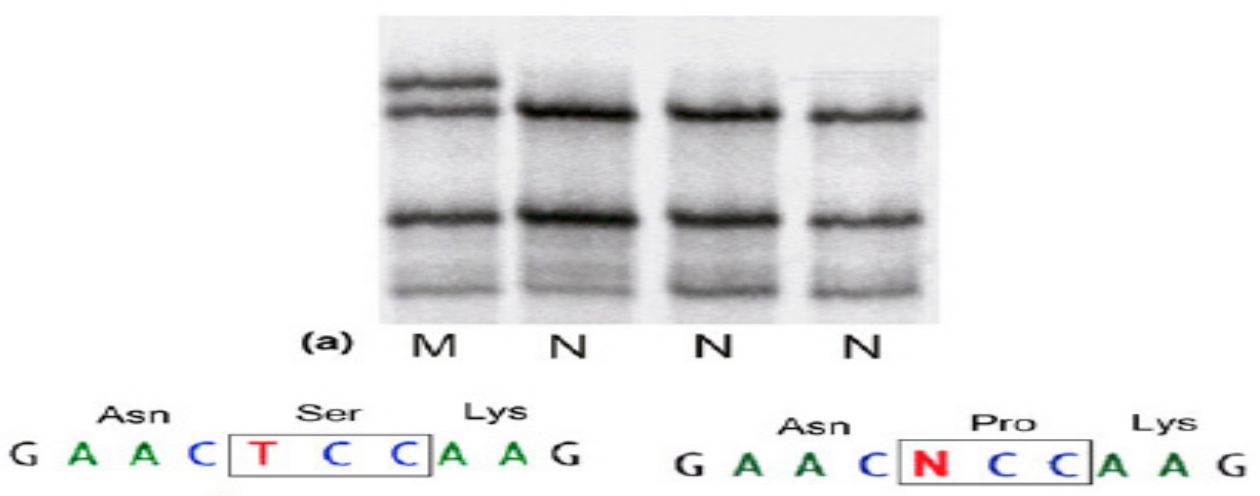

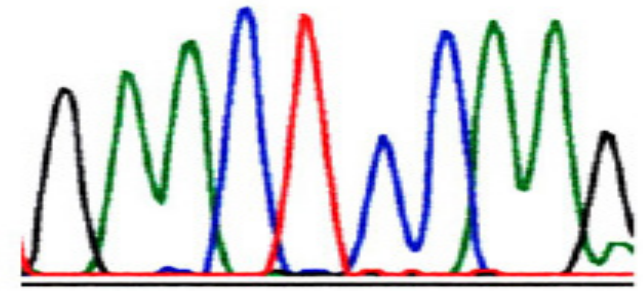

(b)

Normal

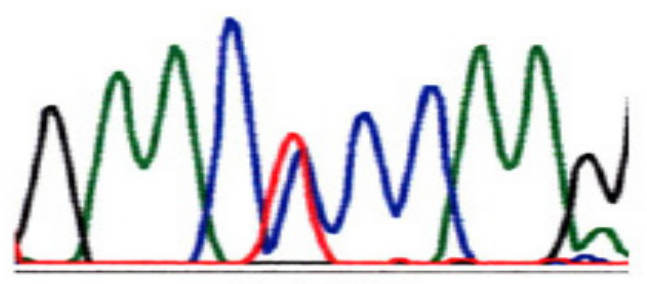

S143P

Figure 3: Schematic view of the nucleotide sequence of target mutated genes in patients with Duchenne scrotum dystrophy compared to normal group.
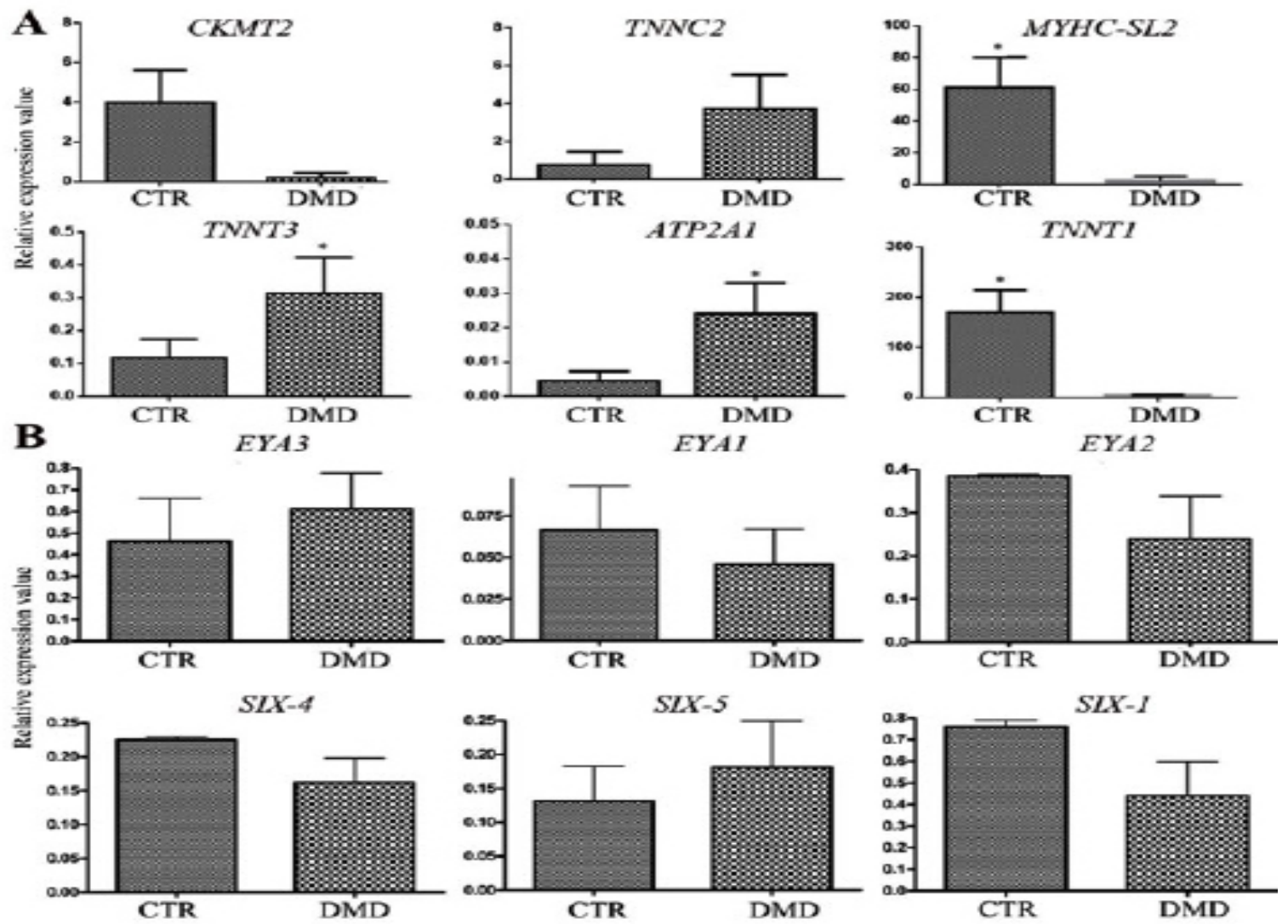

Figure 4: Schematic representation of the expression mutated genes expression diagram in patients with Duchenne scrotum dystrophy with MHC expression changes compared to normal group. 


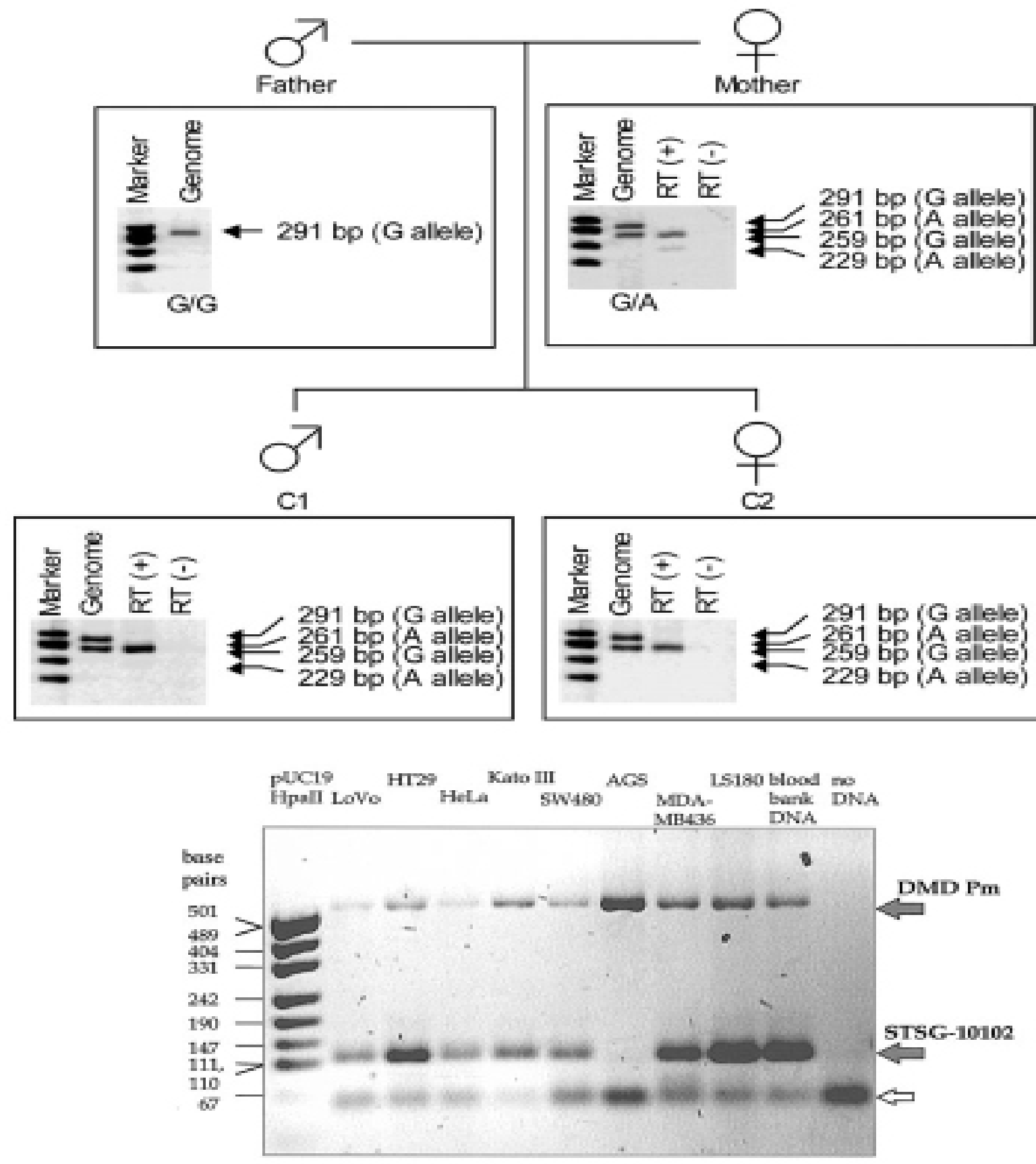

Figure 5: Schematic view of the formation of a target mutated genes band in patients with Duchenne scrotum dystrophy with a pattern of bond formation in parent genes carrying Duchene muscle dystrophy target mutations. 


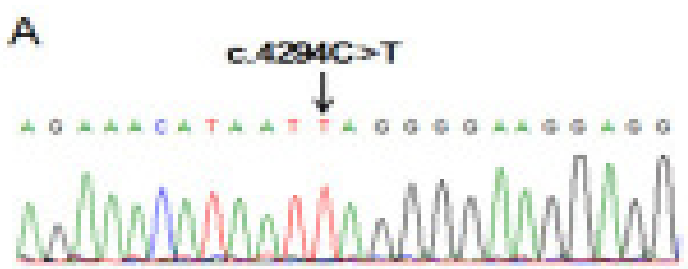

B

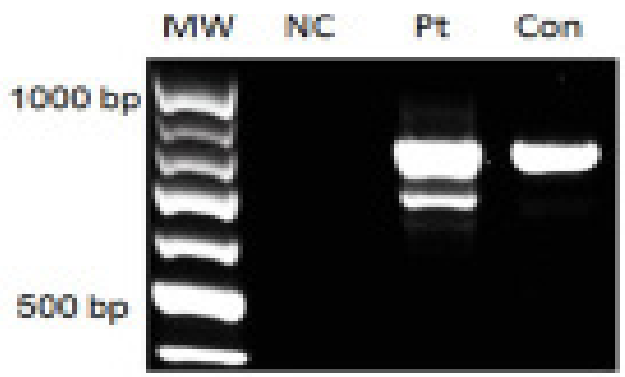

$\mathrm{C}$

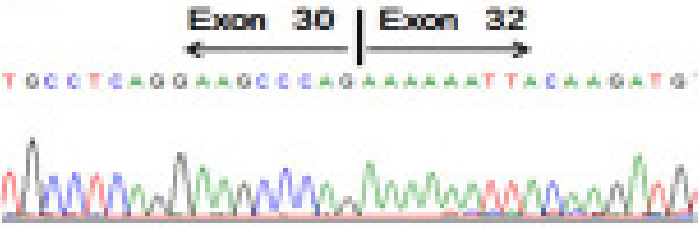

D

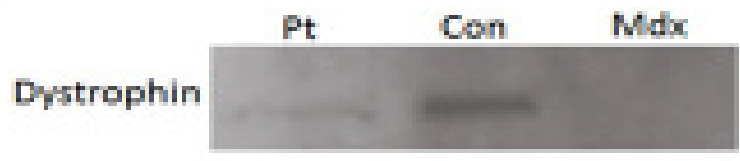

MHC

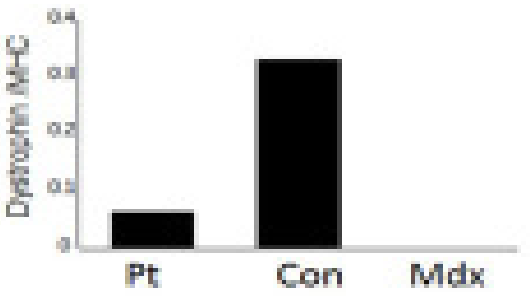

$76 \mathrm{r}$

$24 \%$
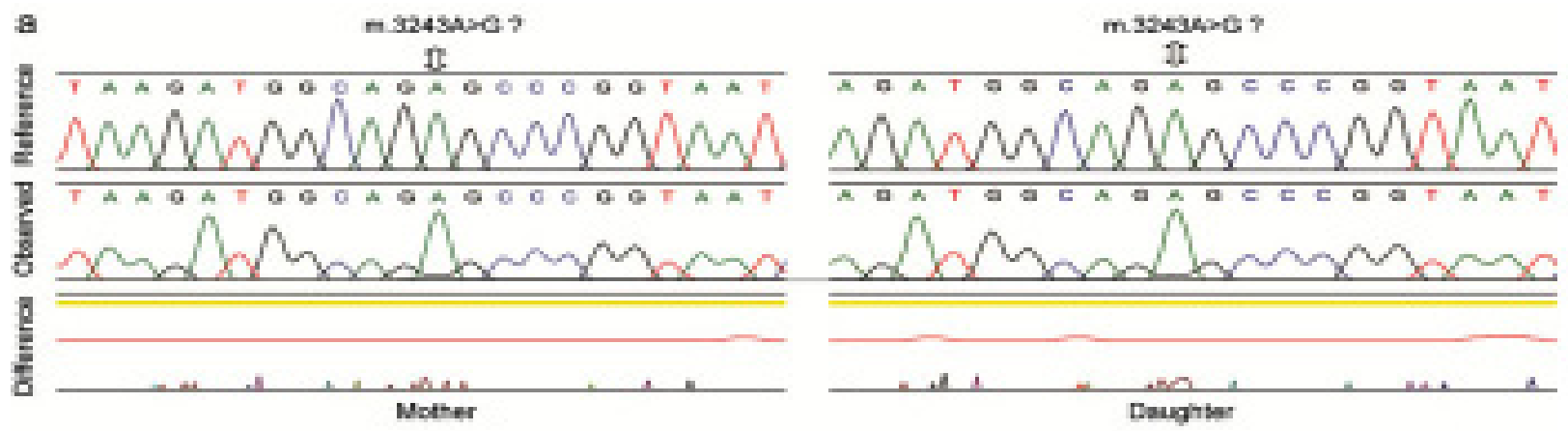

b

\begin{tabular}{|c|c|c|c|c|c|c|c|c|c|c|c|c|c|c|c|c|c|}
\hline \multirow{2}{*}{ Pumbed } & \multirow{2}{*}{ Paber } & \multirow{2}{*}{ Eres } & \multirow{2}{*}{\multicolumn{2}{|c|}{ Fat cenerapt }} & \multicolumn{5}{|c|}{ 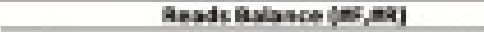 } & \multicolumn{7}{|c|}{ 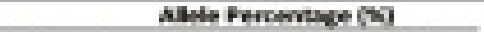 } & \multirow{2}{*}{ Mutasen } \\
\hline & & & & & $A$ & $\mathbf{E}$ & E & $\mathbf{T}$ & Ina & [네 & A. & c & G & $\mathbf{T}$ & m & Del & \\
\hline Muth & 1245 & FantI & a & 19atd & solsait. & 10 & wotes & 4 & 60 & -50 & 525 & $a$ & 7.11 & 96 & 9 & 0 & Ang \\
\hline Hughir & 1294 & malt & 1 & $7+\%$ & 4at 6ik & 71 & $417+14$ & 51 & ba & Eñ & Fit & od: & $4.8 \mathrm{a}$ & $\mathbf{a r}$ & a & a & wh \\
\hline
\end{tabular}

Figure 6: Schematic View of the Formation of the Dystrophin-mutated Gene Genes in Patients with Duchenne Sciaticular Dystrophy with the Bond Formation in the Genes of the Mothers and Daughters of the Duchenne Muscular Dystrophy Mutations. 
A
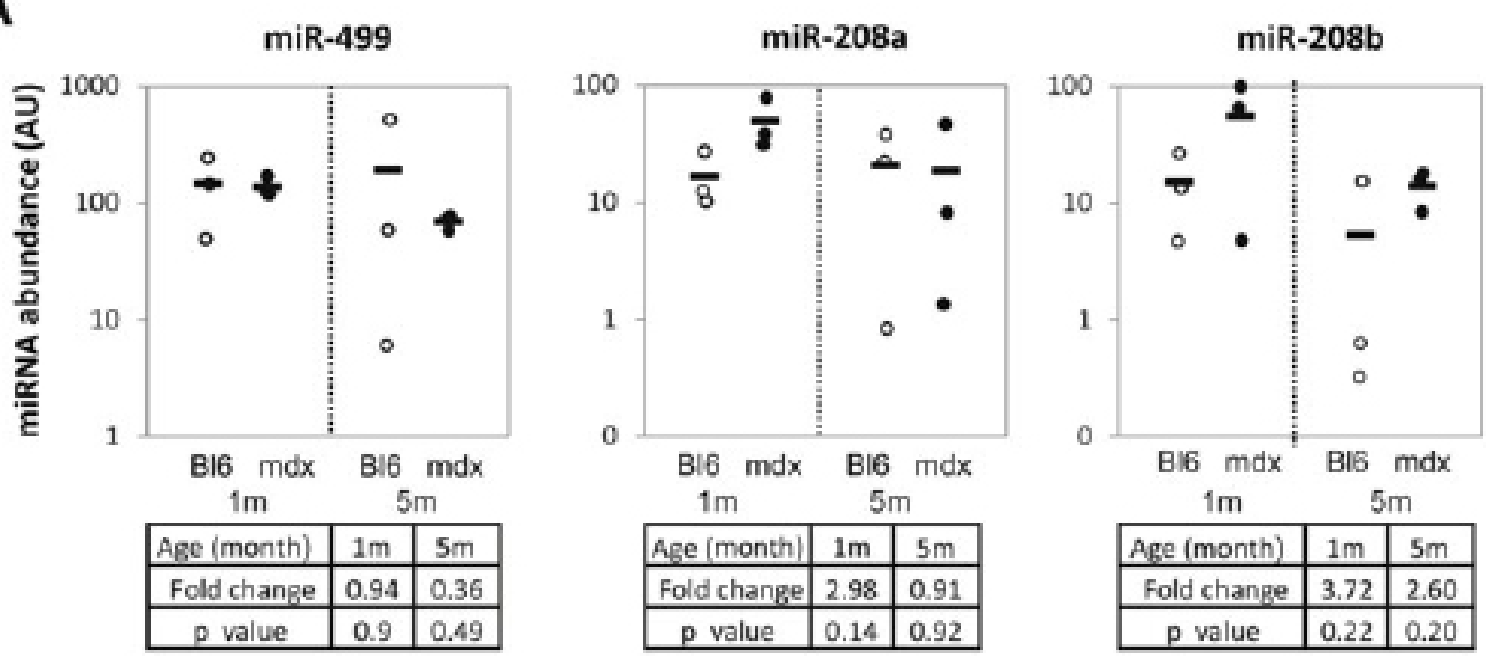

B
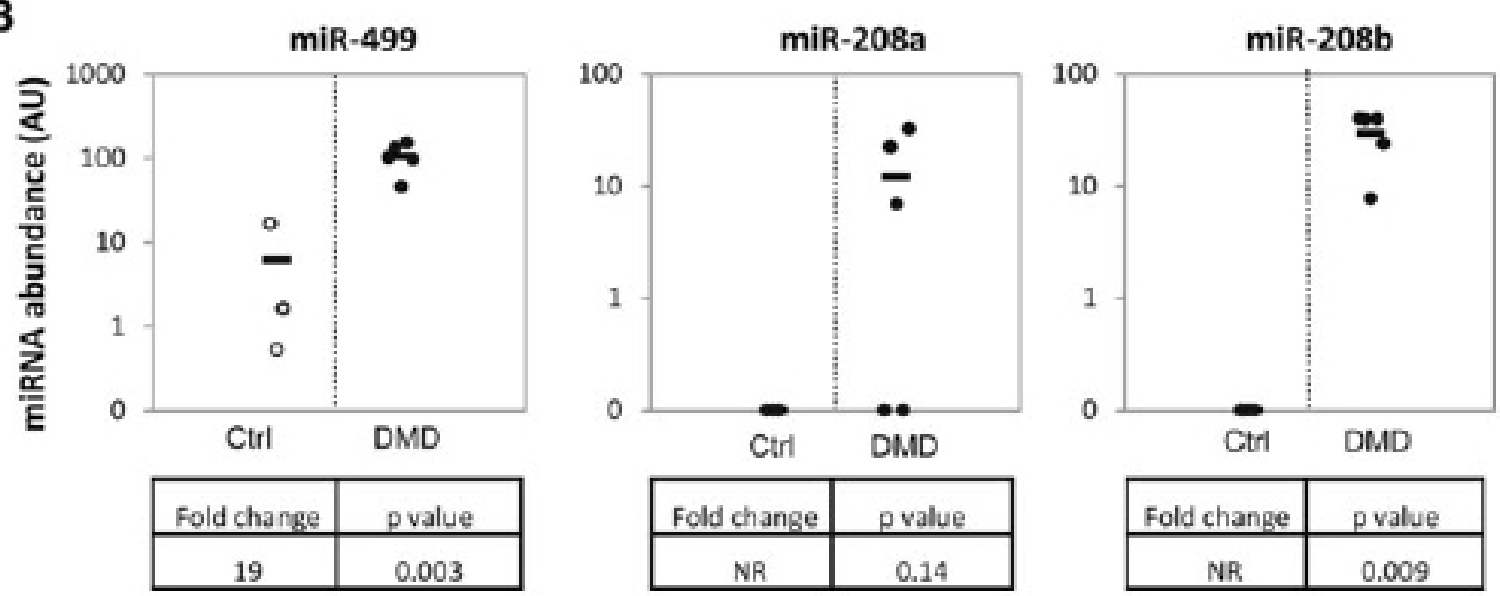

Figure 7: Schematic view of the pattern of altered mirna expression of dystrophin in patients with Duchenne Muscular Dystrophy.
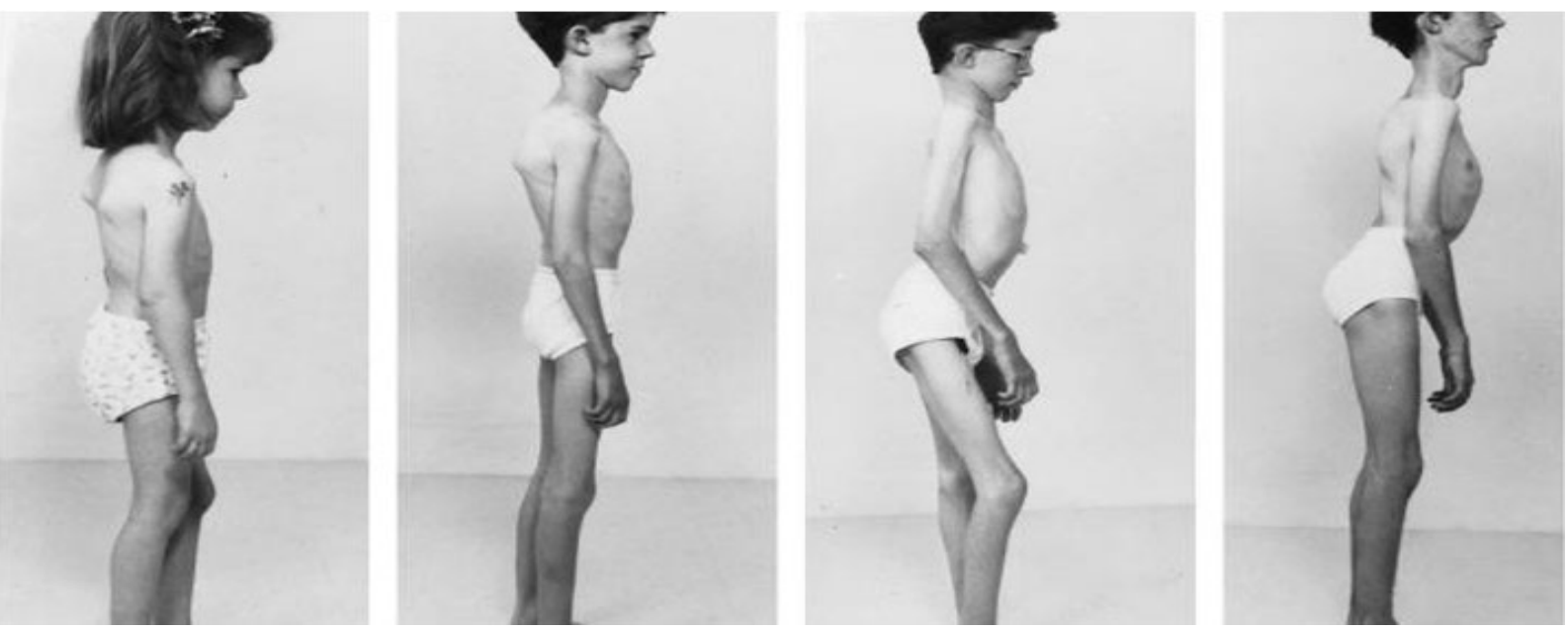

Figure 8: Images of Children with Duchenne Muscular Dystrophy.

Citation: Shahin A, Vida VK, Rana B, et al. (2017) Assessment of Genetic Mutations DMD, DYSF, EMD, LMNA, DUX4, DMPK, ZNF9,

PABPN1 Genes Induction Duchenne Muscular Dystrophy. SOJ Immunol 5(2): 1-8. 


\section{Discussion}

According to studies by Goemans NM and colleagues in 2011, similar results were obtained with the results of this study in the study of genetic mutations effective in Duchenne disease. Since this study was the first in Iran, so the need for further research into the Duchenne disease should be created by other scholars of the world for different human races in the world.[Figure 9]

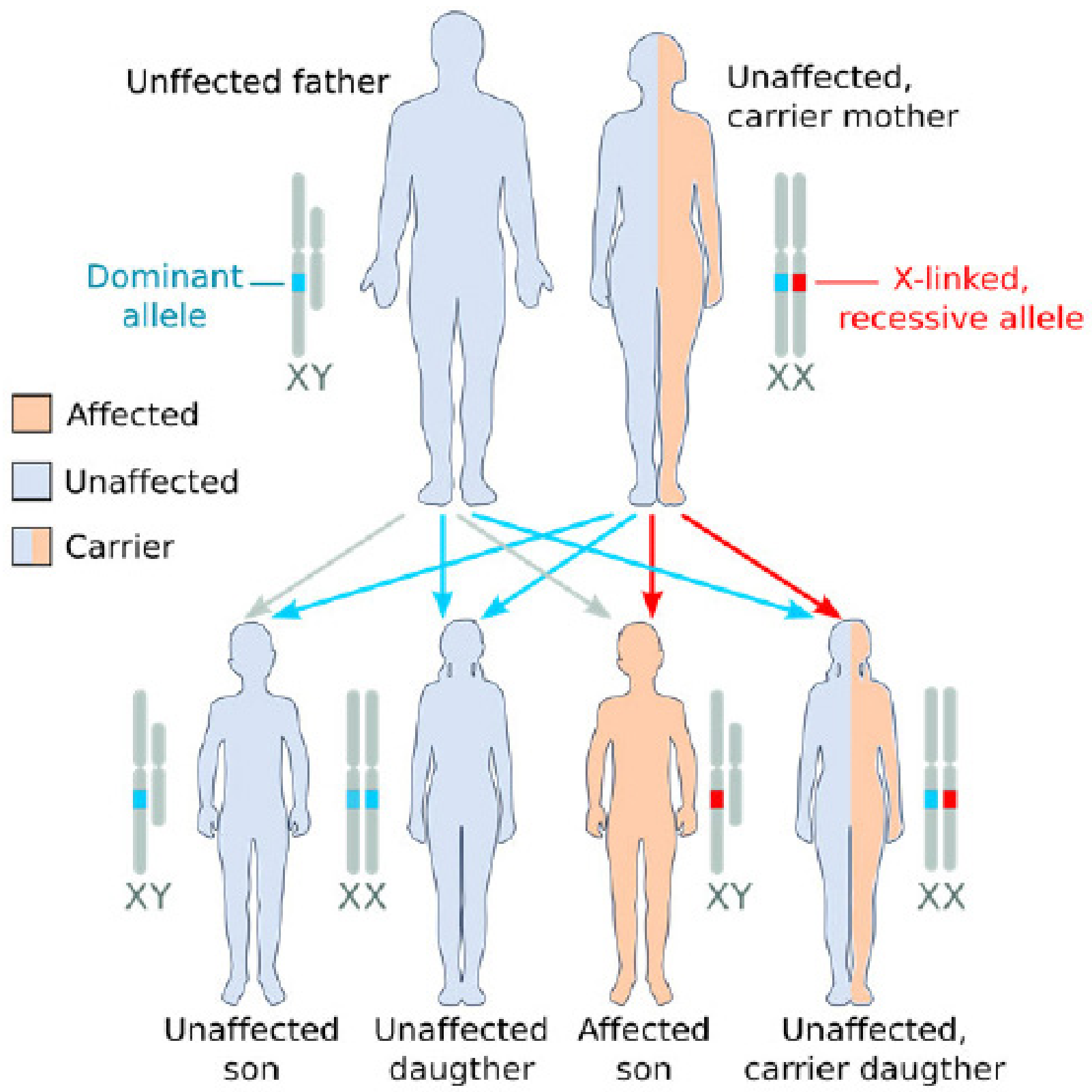

Figure 9: schematic view of an X Linked-recessive hereditary pattern that Duchenne muscular dystrophy also follows this pattern.

\section{Conclusion}

According to the results of sequencing the genome of patients with Duchenne muscular dystrophy disease, and the genetic mutations DMD, DYSF, EMD, LMNA, DUX4, DMPK, ZNF9, PABPN1genes found that about $100 \%$ of patients with Duchenne muscular dystrophy disease, they have this genetic mutations. Patients with Duchenne muscular dystrophy disease, unusual and frightening images in the process of Duchenne muscular dystrophy disease, experience. Lot epigenetic factors involved in Duchenne muscular dystrophy disease. But the most prominent factor to induce Duchenne muscular dystrophy disease, mutations is DMD, DYSF, EMD, LMNA, DUX4, DMPK, ZNF9, PABPN1 genes. This gene can induce the birth and can also be induced in the adulthood. 


\section{References}

1. Muscular dystrophy: hope through research. NINDS. 2016

2. Rowland, L. P. Clinical perspective: phenotypic expression in muscular dhystrophy. In R. C. Strohman \& S. Wolf (eds.), gene expression in muscle. New york, NY: Plenum Press. 1985;3-5

3. Nicholson LV, Johnson MA, Bushby KM, Gardner-Medwin D, Curtis A, Ginjaar IB, et al. Integrated study of 100 patients with Xp21 linked muscular dystrophy using clinical, genetic, immunochemical, and histopathological data. Part 1. Trends across the clinical groups. J Med Genet. 1993; 30(9): 728-736.

4. Muntoni F. Is a muscle biopsy in Duchenne dystrophy really necessary? Neurology. 2001; 57(4): 574-575.

5. Flanigan KM, Andrew VN, Dunn DM, Alder J, Mendell JR, Weiss RB. Rapid Direct Sequence Analysis of the Dystrophin Gene. AJHG. 2003; 72(4): 931-939; Doi: 10.1086/374176

6. Dany A, Barbe C, Rapin A, Réveillère C, Hardouin JB, Morrone I, et al. Construction of a quality of life questionnaire for slowly progressive neuromuscular disease. Quality Life Res.2015; 24 (11): 2615-2623; Doi: $10.1007 / \mathrm{s} 11136-015-1013-8$

7. Falzarano MS, Scotton C, Passarelli C, Ferlini A. Duchenne muscular dystrophy: from diagnosis to therapy. Molecules. 2015;20(10): 18168-18184; Doi: 10.3390/molecules201018168

8. Marques MJ, Ferretti R, Vomero VU, Minatel E, Neto HS. Intrinsic laryngeal muscles are spared from myonecrosis in the $\mathrm{mdx}$ mouse model of Duchenne muscular dystrophy. Muscle nerve. 2017;35(3): 349-353; Doi: 10.1002/mus.20697

9. Ferretti R, Marques MJ, Khurana TS, Santo Neto H. Expression of calcium-buffering proteins in rat intrinsic laryngeal muscles. Physiol Rep. 2015;3(6): e12409; Doi: 10.14814/phy2.12409

10.De rosa G. Da conte a Duchenne [by conte in Duchenne]. Dm (in Italian). Unione italiana lotta alla distrofia muscolare.2005.

11. Dunckley MG, Manoharan M, Villiet P, Eperon IC, Dickson G. Modification of splicing in the dystrophin gene in cultured mdx muscle cells by antisense oligoribonucleotides. Hum Mol Genet. 1998;7(7): 1083-1090

12. Goemans NM, Tulinius M, van den Akker JT, Burm BE, Ekhart PF Heuvelmans N, et al. Systemic administration of PRO051 in Duchenne's muscular dystrophy". N Engl J Med. 2011; 364(16):1513-1522; Doi: 10.1056/NEJMoa1011367

13. England SB, Nicholson LV, Johnson MA, Forrest SM, Love DR, Zubrzycka-Gaarn EE, et al. Very mild muscular dystrophy associated with the deletion of $46 \%$ of dystrophin. Nature.1990;343(6254): 180182; Doi: $10.1038 / 343180 \mathrm{a} 0$

14. Wilton SD, Lloyd F, Carville K, Fletcher S, Honeyman K, Agrawal S, et al Specific removal of the nonsense mutation from the mdx dystrophin mRNA using antisense oligonucleotides. Neuromuscul disord. 1999; 9(5): 330-338.

15. Goyenvalle A, Vulin A, Fougerousse F, Leturcq F, Kaplan JC, Garcia $\mathrm{L}$, et al. Rescue of dystrophic muscle through u7 snRNA-mediated exon skipping. Science. 2004; 306(5702):1796-1799; Doi: 10.1126/ science.1104297

16. Morgan JE, Pagel CN, Sherratt T, Partridge TA. Long-term persistence and migration of myogenic cells injected into pre-irradiated muscles of mdx mice. J Neurol Sci. 2003;115(2):191-200; Doi: 10.1016/0022-510X(93)90224-M
17. Dellavalle A, sampaolesi M, Tonlorenzi R, Tagliafico E, Sacchetti B, Perani L, et al. Pericytes of human skeletal muscle are myogenic precursors distinct from satellite cells. Nature Cell biology. 2007; 9(3): 255-267; Doi: 10.1038/ncb1542

18. Rodino-Klapac LR, Chicoine LG, Kaspar BK, Mendell JR. Gene therapy for Duchenne muscular dystrophy. Arch Neurol. 2007;64(9):12361241; Doi: 10.1001/archneur.64.9.1236

19. Sebahattin C, Virginia AG, Michela G, Lucy F, Silvia T, Karen A, et al. Exon skipping and dystrophin restoration in patients with Duchenne muscular dystrophy after systemic phosphorodiamidate morpholino oligomer treatment: an open-label, phase 2, dose-escalation study. Lancet. 2011; 378(9791): 595-605; Doi: 10.1016/S01406736(11)60756-3

20.Spreitzer H. Rimeporide. Österreichische apothekerzeitung (in German). 2015; 69(11):12.

21.Cavazzana-Calvo M, Payen E, Negre O, Wang G, Hehir K, Fusil F, et al. Transfusion independence and HMGA2 activation after gene therapy of human $\beta$-thalassaemia. Nature. 2010; 467(7313):318-322; Doi: $10.1038 /$ nature09328

22. Yang ZJ, Zhang YR, Chen B, Zhang SL, Jia EZ, Wang LS, et al. Phase I clinical trial on intracoronary administration of Ad-hHGF treating severe coronary artery disease. Mol Biol Rep. 2009; 36(6): 1323-1329; Doi: $10.1007 / \mathrm{s} 11033-008-9315-3$

23. Hahn W, Pyun WB, Kim DS, Yoo WS, Lee SD, Won JH, et al. Enhanced cardioprotective effects by coexpression of two isoforms of hepatocyte growth factor from naked plasmid DNA in a rat ischemic heart disease model. J Gene Med. 2011;13(10): 549-555; Doi: 10.1002/jgm.1603

24. Deev RV, Bozo IY, Mzhavanadze ND, Voronov DA, Gavrilenko AV, Chervyakov YV, et al. pCMV-vegf165 Intramuscular Gene Transfer is an Effective Method of Treatment for Patients with Chronic Lower Limb Ischemia. J Cardiovasc PharmacolTher.2015;20(5): 473-482;Doi: $10.1177 / 1074248415574336$

25. Aiuti A, Biasco L, Scaramuzza S, Ferrua F, Cicalese MP, Baricordi C, et al. Lentiviral hematopoietic stem cell gene therapy in patients with Wiskott-Aldrich syndrome. Science. 2013; 341(6148) :1233151; Doi: 10.1126/science.1233151

26. Lee TW, Southern KW. Topical Cystic Fibrosis Transmembrane Conductance Regulator Gene Replacement for Cystic Fibrosis-Related Lung Disease. Cochrane Database Syst Rev. 2013;(11): CD005599; Doi: 10.1002/14651858.CD005599.pub4

27. MacLaren RE, Groppe M, Barnard AR, Cottriall CL, Tolmachova T, Seymour L, et al. Retinal Gene Therapy in Patients with Choroideremia : Initial Findings from a Phase $1 / 2$ Clinical Trial. Lancet. 2014; 383(9923):1129-1137; Doi: 10.1016/S0140-6736(13)62117-0

28. Tebas P, Stein D, Tang WW, Frank I, Wang SQ, Lee G, et al. Gene editing of CCR 5 in autologous CD4 T cells of persons infected with HIV. N Engl J Med. 2014; 370(10):901-910; Doi: 10.1056/NEJMoa1300662

29. Thrasher AJ, Gaspar HB, Baum C, Modlich U, Schambach A, Candotti F, et al. Gene Therapy: X-SCID Transgene Leukaemogenicity. Nature. 2006; 443 (7109): E5-E6; Doi: 10.1038/nature05219

30. Blaese RM, Culver KW, Miller AD, Carter CS, Fleisher T, Clerici M, et al. T lymphocyte-directed gene therapy for ADA- SCID: initial trial results after 4 years. Science. 1995; 270(5235): 475-480. 